\title{
Exploratory Study Based on Stakeholder Theory in the Development of Accounting Information Systems in the Catholic Church: A Case Study in the Archdiocese of Semarang, Indonesia
}

\author{
Fransiscus Asisi Joko Siswanto ${ }^{1}$, Francisca Reni Retno Anggraini ${ }^{1}$, and Bernardinus Sri \\ Widodo $^{2}$ \\ ${ }^{1}$ Accounting Department, Sanata Dharma University, Mrican Tromol Pos 29, Yogyakarta, Indonesia \\ ${ }^{2}$ Sanata Dharma Mecatronics, Paingan Maguwoharjo Sleman, Yogyakarta, Indonesia
}

\begin{abstract}
This study aims to find a strategy in the development of computer-based accounting information system in the church. With exploratory study on the theory of stakeholders, this study identifies the needs of financial information for the purposes of making a decision required by the parish priest, the parish treasurer, and a team of economists at the archdiocese of Semarang (AS). This research was conducted by using qualitative and quantitative approach. Qualitative method is conducted by applying a focus group discussion with economist team in AS (the users who have major influence in the development of the system). In addition to that, quantitative method is also applied to the parish treasurer (the users who have great interest in the system development). The results showed that the parish treasurer has high perceived usefulness, perceived ease of use, perceived of relevance, and the self-efficacy toward the accounting information system (AIS) for the parish. This study provides an answer on the benefits of a bottom-up strategy based on the stakeholder analysis in the development of AIS in the area of the Catholic Church AS.
\end{abstract}

\section{Introduction}

Research on the usefulness of accounting information systems at religious organizations is still an interesting issue. [1] says that many issues arise in the implementation of computer-based information system on a voluntary organization. Such issues are cultures, small budgets, users who work voluntarily, and the complexity of the organization purposes, etc. Therefore, a specific strategy is needed in the development of information systems within the organization.

The Catholic Church has a specific organizational structure. It is the sacred papal throne at the top, the dioceses, and the parishes at the lowest. The lower institutions will be responsible to the upper institutions. In 2008, the Archdiocese of Semarang (AS) has made accounting information system for the parish as outlined in the Technical Guidelines of 
Parish Finance and Accounting. It was designed with the aim to materialize the credibility of the Church in terms of finance and accounting that are expected to enhance the visionary and credibility of the ecclesiastical property management. After being applied for almost seven years, some obstacles have been encountered. There have been discrepancies in the practice between the guidelines that are over-complex and the software of General Ledger (GL) which is not easily applied. This resulted in the expected goals which have not been fully achieved. This condition is supported by the research conducted by [2] who found that there is high user resistance. The results of their research also showed that the resistance is influenced by the low performance which is far from expectancy.

Based on the preliminary observations, the development of parish accounting information systems is applied by top down policy so that it may cause the inability of the system to be implemented properly. The weakness of the top down strategy is the lack of ability to accommodate the needs and abilities of the user so that the user considers the system difficult to run. This might be the cause of the low performance which is far from expectancy. Based on this condition, the research was conducted with the exploratory study based on the stakeholder theory to discover an effective strategy in both the preparation and implementation of the computer-based accounting information systems for the church. The exploratory study identifies the needs of financial information for the purpose of making a decision required by the parish priest, the parish treasurer, and the team of economists at the archdiocese of Semarang (AS).

This study aims to find the right strategy in the development of accounting information system (AIS) of the parish. In this case the study is more focused on the lowest organizational unit of the church, the parish. The research question in this study is whether the AIS which is developed from the stakeholder analysis can increase the perceived usefulness, perceived ease of use, perceived of relevance, and the user's self-efficacy.

This research is based on the stakeholder theory to identify and explore the needs of the users of accounting information system of the parish. The theory of stakeholders is still rarely used in the research on non-profit organizations [3]. The main user of accounting information is the parish priest, the parish treasurer, and the bishop of the diocese (represented by the economist team). The parish priest and the parish treasurer require accounting information to take a decision on the level of the parish, to analyze the performance of the parish and the units under the parish, while the bishop uses it to determine the subsidies provided to the parishes and to examine the financial performance of it.

The results of this study show that the parish treasurer of AIS for parish recognizes the high perceived usefulness, the perceived ease of use, the perceived of relevance, and the user's self-efficacy. This research gives contribution to AIS development theory that stakeholder analysis is beneficial in the development of AIS, especially in religious organization. This research also gives contribution to Archdiocese of Semarang in developing AIS of the parish.

\section{Literature Review}

\subsection{Stakeholder Theory}

As presented by [3], the stakeholder theory is first proposed by Freeman (1984) and the theoretical development has been done by Donaldson and Preston (1995) and Mitchell et al. (1997). Donaldson and Preston (1995), in [3], states that the theory of stakeholders can be explained with three views: (1) descriptive (stakeholders related to the organization 
operations), (2) the normative (related to the goal of developing the moral guidelines for determining the managerial response to the stakeholder), (3) instrumental (exploring the connection between the stakeholder management and the objectives of the company). Cooper (2014) states that the stakeholders can be identified based on the power to influence, the legitimacy of the relationship, and the urgency of the claims of the stakeholders. Nuseibeh and Easterbrook (2000) in [4] defines stakeholders as individuals or organizations that benefit or suffer losses due to the success or failure of a system. In designing a system, the stakeholders are managers, designers, and users of the system. Further [4] states that because the stakeholders are all people who are affected by or who receive the impact on the system designing, they need to be considered in the design. Their perspectives are sometimes contradictory therefore the system designers should accommodate their different opinions. Therefore [4] suggests that the system designer shall pay greater attention to the users of the system implemented earlier, since they have more experience in using the earlier system. Their opinions can be used as a basis to meet their needs. However, considering the users of the system only would not be enough to achieve success in the design and implementation of the system. The designers should also identify the needs of other stakeholders. Freeman (1984) in [5] states that in the non-profit organization recognizing the stakeholders is an important factor in the face of a changing environment and involving stakeholders in the management is the most effective strategies for achieving organization success.

[3] states that the recent stakeholder theory is assumed to be able to explain the various conflicts of interest in non-profit organizations. Benjamin (2008), [3], states that the stakeholders in non-profit organizations are donators, the party receiving the benefit (beneficiaries), the regulator, and the organization partners. Accountability in a non-profit organization includes upward (corresponding to funders or donators), lateral (related to staff members) or / and downward (to the client). Speckbacher (2008) in [3] states that nonprofit organization's stakeholders can be divided into internal stakeholders (composing of managers and volunteers) and external (composing of funders). Stakeholders in the Catholic churches include the economist team in archdiocese (middle managers), the parish priest (lower level managers), the system user (parish treasurer) and the donators (parishioners and other funders). Economist team in archdiocese establishes policies related to finance which will be implemented in all the parishes in the Archdiocese. The parish priest is making policies at the parish level. Parish treasurer manages and reports the financial administration to the parish priest and economist team in archdiocese. Parishioners and other donators need financial reports to assess the accountability of the church.

\subsection{Stakeholder Analysis}

The term of stakeholder analysis is introduced by Freeman (1984) in his book Strategic Management in [4]. Nuseibeh and Easterbrook (2000), in [4], state that the requirement of system software starts with basic assumption that there is a wide range of stakeholders who have different desires and may be conflicting. A solution that meets the objectives of all stakeholders and also eliminates (reduces) the conflicts is found by systematic exploration.

The steps in stakeholder analysis are: (1) Identifying the organization stakeholders and the ability to choose the key stakeholders of the organization is the most important thing because key stakeholders are people or organizations that are concerned with the system designed, (2) Making a priority of stakeholders, stakeholders can be grouped into four groups, namely: (a) high influence, high interest, (b) low influence, high interest, (c) high influence, low interest, (d) low influence, low interest, (3) Understanding the perspective of the stakeholders, the best way to understand the stakeholders is to conduct 
semi-structured interview by asking open-ended questions to start a discussion, (4) Accommodating the stakeholders' perspectives into the design of the system, it is the most difficult stage because the system designer must accommodate all the interests that are sometimes contradictory.

\subsection{Technology Acceptance Model (TAM)}

TAM is a model which is introduced by [6]. TAM argues that individual acceptance toward information technology (IT) is influenced by perceived usefulness (PU) and perceived ease of use (PEU). [7] found that user's self-efficacy (SE) influences PEU and perceived of relevance (PR) influence PU. It means PU, PEU, PR, and SE influences the individual acceptance toward IT. PU is the extent to which a person believes that using a technology will enhance her or his performance. PEU is the extent to which a person believes that using a technology will be free of effort. PR is the extent to which a person believes that the capability of a system to enhance the individual's job performance. Then, $\mathrm{SE}$ is the belief that the IT has capability to perform a particular behavior.

\section{Research Method}

Research design of this study is sequential exploratory so it is conducted using mixed method that is qualitative and qualitative approach. Qualitative method is done by focus group discussion (FGD) with economist team in AS (users has major influence in the development of the system) in order to develop AIS of the parish. Furthermore, quantitative method is applied by conducting the survey to the parish treasurer in order to examine their PU, PEU, PR, and SE.

This research was conducted with a case study on AS, which currently has a need to establish a new AIS that replaces the old one. Sequential exploratory research is conducted for problem solving. The research is started by setting the area in which the problem is found, then literature review is used to guide researcher collecting the data and data analysis. The data and data analysis are used to state the hypothesis.

\section{Analysis}

\subsection{Preliminary Study}

The results of the research conducted by [2] showed the users' reluctance of using the accounting software for parish based GL, because it is difficult to use. It may cause the low expectancy to GL. Based on FGD with a team of economists AS, we obtained information that AS needs parish's financial information to decide the parish which should get subsidy and how much it is.

Furthermore, [2] states there is low expectancy on the GL software for the parish treasury. It is caused by the nature of their work which is voluntarily and the GL software which is not user friendly. They just want their work can be completed easily and in a simple way. We suspect that the low expectancy on the GL software may not be caused only by the nature of their work which is voluntarily but also that they have little knowledge and computer skills.

\subsection{Stakeholder Analysis}

\subsubsection{Identifying organizational stakeholders}


Based on the results of early studies, researchers suspect that the source of the failure of the application of the accounting system for the parishes is due to the lack of ability of the parish treasurer to use computers therefore they want software that is easy to use, yet can produce financial reports quickly. The stakeholders of AIS of the parish are a team of economists of diocese, parish priest, parish treasurer, parishioners, and other donators.

\subsubsection{Making a priority stakeholders}

After identifying the stakeholders, the researchers then grouped the stakeholders as follows. Stakeholders with high influence and high interest is a team of economists at the diocese, stakeholders having low influence and high interest is the parish treasurer, stakeholders having high influence but low interest is parish priest and stakeholders who have low influence and low interest are parishioners and other donators.

\subsubsection{Understanding the perspective of stakeholders}

Each parish treasurer was given a questionnaire obtaining about their experience with the financial information system program or the program which is still in use, and their expectations of the new system program. Based on the results the majority of respondents did not know about the General Ledger program that had been used by the parish. The majority of the respondents expect that there is a new program used to process financial transaction data in their parishes. A team of the economist diocese wants an easy to use accounting software so that the financial information for the diocese will be accepted quickly, and the decisions related to finances can be done quickly. Parish priest also wants accounting software to be easily used, that he can take decision quickly. Parishioners and other donators do not require reports quickly but they require transparent and accountable report.

\subsubsection{Accommodating the stakeholders' perspective into the design of the system}

Intensive discussion is conducted to a team of the economist diocese that has the authority to make policies relating to the financial administration of the parish. Then, from the discussions, it is discovered that the financial transactions in a church or parish are frequently repetitive transactions. So the accounting system must make special accounting journal to record the transactions, while the transactions which do not occur repeatedly will be processed through the general journal.

\subsection{Survey about user acceptance}

After the parish treasurers are given the training, they are requested to fill the questionnaire. It is conducted to examine the level of user acceptance toward IAS of the parish. The level of user acceptance is determined by PU, PEU, PR, and SE. 


\section{Conclusion}

The Catholic Church organization is specific that it is structured from the highest to the lowest, the sacred papal throne, dioceses, and parishes. The Parishes are administered voluntarily by the people who live in it. To achieve its vision and mission, the Catholic Church aspires to provide financial information that is transparent and accountable. In 2008, the Archdiocese of Semarang (AS) has implemented an accounting information system for the parish as outlined in the Parish Technical Guidelines for Finance and Accounting. It is prepared with the aim to materialize the credibility of the Church in terms of finance and accounting Parish. It is expected to enhance/accelerate the visionary and credibility of the ecclesiastical property management.

We identify that the stakeholder of the parish accounting information system is a team of economists at AS, the parish priest, the parish treasurer, and parishioners and other donator. The stakeholders with high influence and high interest is a team of economists at the diocese, while the stakeholders who have low influence and high interest is the parish treasurer, and the stakeholders who have high influence but low interest is the parish priest and the stakeholders who have low influence and low interest are parishioners and donators. The parish treasurers are the person who is the most accountable to prepare and provide parish financial statements. But, they work voluntarily by using/sharing their spare time along with their main job. Therefore, they need tools in order to present financial reports quickly and accurately.

Based on the survey, we found that PU, PEU, PR, and SE of the users toward the IAS are high. It means that the stakeholder analysis can be used as the strategy in developing of AIS in the parish. Although the study found a new strategy of development of accounting information systems, but this study has limitations, for example, the results of this study are highly specialized and only suitable for the organization of the Catholic Church. In addition, the research is more qualitative than quantitative therefore it is more in the form of subjective interpretations of the object studied.

\section{References}

1. G.G. Morgan. J. of Strat. Inf. Syst., 4,3 (1995)

2. A.D. Kuntara, I. I.H. Suryandari, dan A.F. Prasetyawan. Working Paper (2015)

3. K.R. Cooper. Dissertation (2014)

4. J. Bauntelle. http://boxesandarrows.com/understanding-organizational- stakeholdersfor-design-success/ (2004)

5. M. Shimaoka. The 2nd International conf. on Gov. Perf. Mgt. and Leadership, Portland State University (2011)

6. Davis, F.D., Bagozzi, R.P., and Warshaw, P.R. Mgt. Sc., 35,8 (1989)

7. Venkatesh, V., and Davis, FD. Mgt. Sc.,46,2 (2000) 